\title{
JOURNAL.RU
}

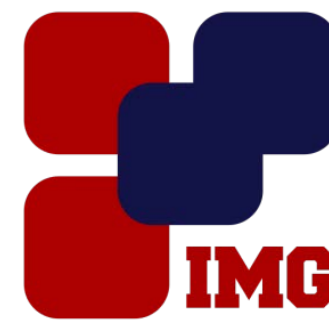

IVANOV
MaNagement
GROUP

Никитина А.А, Каликин И.Н. Омский государственный аграрный университет Омск, Россия

doi: 10.18411/lj-30-04-2017-2-12

idsp 000001:lj-30-04-2017-2-12

\section{Ветеринарно - санитарная оценка творожков для детского питания}

\section{Аннотация}

О целебных свойствах молочной продукции известно очень давно. Благодаря присутствию кальция в своем составе, молочные продукты способствуют росту волос и укреплению костей. Для полноценного роста и развития подрастающему организму необходим целый комплекс полезных и питательных веществ. Наилучшим решением для перехода ребенка к взрослой пище является введение в рацион творога, который богат витаминами и макроэлементами необходимыми для полноценного роста и развития ребенка.

Ключевые слова: Творог, здоровое питание, развитие, ассортимент, детский организм, кислотность, содержание белка

Для любого человеческого организма, а в большей мере для детского, необходима полноценная, здоровая пища. Положительное влияние на микрофлору кишечника оказывают кисломолочные продукты. Они оздоравливают организм, насыщают его необходимыми полезными веществами. Широкое применение в детском питании отводится творогу. Ко всем продуктам детского питания предъявляются очень строгие требования. Для изготовления детского творожка используют только кисломолочные продукты, прошедшие термическую обработку.

Изготовление детского творожка производится путем молочнокислого брожения, при изготовлении используется только чистое и свежее молоко. Главным отличием от обычного творога является жидкая консистенция, пониженный уровень кислотности и отсутствие комков. 
В большинстве случае, родители отдают свое предпочтение детским творожкам «Агуша» и «Тема». Именно эти образцы мы решили взять для своих исследований.

Таблица 1

Сравнительная оченка детских творожков с требованиями ГОСТ 32927 - 2014 «Творог для детского питания. Технические условия»

\begin{tabular}{|c|c|c|c|}
\hline $\begin{array}{c}\text { Наименование } \\
\text { показателей }\end{array}$ & $\begin{array}{c}\text { Требования ГОСТ 32927 - } \\
20014\end{array}$ & $\begin{array}{c}\text { Детский творог } \\
\text { «Агуша» }\end{array}$ & Детский творог «Тема» \\
\hline Белок, $\%$ & $7-17$ & 8,4 & 9,1 \\
\hline Кислотность, ${ }^{\circ} \mathrm{T}$ & Не более 150 & 121 & 134 \\
\hline
\end{tabular}

Исследуемые образцы детских творожков по содержанию кислотности и белка полностью соответствуют требованиям ГОСТ 32927 - 2014 «Творог для детского питания. Технические условия». Детские творожки улучшают пищеварение, повышают иммунитет, укрепляют кости и зубы, а так же уменьшают тревогу и стресс.

Одним из главных преимуществ детского творожка является то, что он помогает улучшить пищеварение за счет присутствующих в продукте питательных веществ. Кроме того, он помогает усваиваться питательным веществам из других продуктов питания.

1. $\quad$ ГОСТ 32927 - 2014. Творог для детского питания. Технические условия - Введ. 201601-01.-М.: Изд-во стандартов, 2015.- 8 с.

2. Храмцов, А.Г. Научно-технические основы биотехнологии молочных продуктов нового поколения.[Текст]:учеб. пособие /А.Г.Храмцов, Б.М Синельников, И.А Евдокимов, В.В Костина, С.А. Рябцев. СевКаз ГТУ, 2003 - 118 с. 